\title{
Resistensi Perempuan Tandhak Madura: Berjuang dari Dalam
}

\author{
Farida Nurul Rahmawati ${ }^{1}$, Emy Susanti ${ }^{2}$, Pinky Saptandari ${ }^{3}$ \\ ${ }^{1}$ Mahasiswa Program Doktoral Ilmu Sosial FISIP Universitas Airlangga Surabaya \\ ${ }^{2}$ Prodi Ilmu Sosiologi FISIP Universitas Airlangga Surabaya \\ ${ }^{3}$ Prodi Ilmu Antropologi FISIP Universitas Airlangga Surabaya \\ E-mail:wawafarida@gmail.com
}

DOI: https://doi.org/10.21107/ilkom.v15i1.10046

\begin{abstract}
ABSTRAK
Penelitian ini bertujuan untuk menganalisis resistensi perempuan tandhak Madura melalui pengalaman komunikasi di tengah relasi kuasa yang terjadi atas nama tubuhnya. Penelitian ini merupakan penelitian kualitatif denagn pendekatan Etnografi Feminis. Selain itu, teknik penelitian yang digunakan adalah wawancara, observasi, dokumentasi, dan studi literatur. Hasil penelitian terhadap pengalaman komunikasi perempuan tandhak Madura di tengah relasi kuasa yang terjadi atas nama tubuhnya menunjukkan adanya resistensi yang dilakukan oleh perempuan tandhak Madura baik di lingkungan privat maupun publik. Resistensi yang dilakukan dalam bentuk umpatan dalam hati yang tidak ditunjukkan atau diketahui orang lain, penolakan yang ditunjukkan melalui tingkah laku yang kurang baik, tangisan yang tidak ditunjukkan kepada orang lain. Namun resistensi juga ada yang dilakukan dengan cara mengikuti perbuatan yang diinginkan pemilik kuasa tersebut. Hal ini bukan menunjukan kepatuhan dan tidak berdaya namun merupakan stategi agar tetap survive.
\end{abstract}

Kata Kunci: resistensi, perempuan tadhak Madura, pengalaman komunikasi, relasi kuasa.

\begin{abstract}
This study aims to analyze the resistance of Madurese tandhak women through communication experiences in the midst of power relations that occur on behalf of their bodies. This research is a qualitative research with a Feminist Ethnography approach. The data obtained with interviews, observation, documentation, and literature study. The results show that the midst of power relations on Madurese tandhak women occur on behalf of their bodies resistance. The resistance prevailed in private and public circles. Resistance that is done in the form of insults that are not shown or known to others, rejection that is shown through bad behavior, crying that is not shown to others. However, resistance is also carried out by following the actions desired by the owner of the power. This does not show obedience and helplessness but is a strategy to survive.
\end{abstract}

Keywords: resistance, madurese tadhak women, communication experience, power relations.

\section{Cite this as :}

Rahmawati, Farida Nurul., Emy Susanti., Pinky Saptandari (2021). Resistensi Perempuan Tandhak Madhura: Berjuang dari Dalam. Jurnal Komunikasi, 15(1), 17-28. doi: https://doi.org/10.21107/ilkom.v15i1.10046

Article History :

Received February, 24th 2021,

Acepted 10 March, $2^{\text {th }} 2021$ 


\section{PENDAHULUAN}

Madura dikenal memiliki lokalitas dan keunikan beragam budaya masyarakatnya. Salah satu budaya masyarakat Madura yang menarik untuk diamati adalah keberadaan kesenianTandha'. Masyarakat Madura menggunakan istilah Tandha' untuk mengacu pada dua hal yakni jenis kesenian dan penari perempuan. Pada awalnya istilah Tandha' dilekatkan pada sosok penari perempuan, tetapi karena penari menjadi unsur dominan dalam pertunjukkan, maka jenis kesenian ini juga disebut sebagai Tandha' atau yang biasa juga disebut Tayub atau karawitan. Kebanyakan perempuan yang menjadi Tandha' adalah kaum yang tingkat pendidikannya rendah. Mereka menghibur banyak laki laki dengan suara dan goyangannya. Menari dengan siapa saja yang menginginkannya, menuntut bayaran dan akan membiarkannya menaruh uang tersebut di bagian manapun dari tubuhnya.

Kabupaten Sumenep dikenal sebagai bumi untuk tandha' yang memiliki 28 kelompok kesenian tayub yang tersebar di kecamatan sumenep, kalianget, saronggi, batang batang, dungkek dan gapura. Sedangkan di kecamatan Saronggi sebagai daerah kesenian Tayub tertua, terdapat 8 kelompok kesenian Tayup.

Tandha' sebagai penyebutan terhadap perempuan kesenian tandak atau tayub di Saronggi Madura, dipenuhi dengan beribu makna yang tergantung oleh siapa dia dirumuskan dengan sederet referensi serta kepentingan yang saling berkaitan. Tidak sedikit masyarakat yang memaknai Tandha' sebagai penebar maksiat, penggoda suami, prostitusi terselubung, perempuan rendahan, dan yang sejenis. Sementara kelompok sosial yang lain memaknainya sebagai perempuan tertindas, tereksploitasi, marginal, tidak berdaya dan beragam sebutan lain yang menampakkan posisi powerless.

Sekalipun hampir bisa dikatakan tidak ada kontak seksual yang terjadi antara Tandha' dan penari laki laki di atas pentas, namun suasana pentas tayub selalu dihiasi dengan bahasa bahasa dan gerak gerak yang sangat mudah ditafsirkan sebagai luapan birahi. Di samping itu, tema tema obrolan laki laki tentang Tandha' selalu dalam bahasa bahasa seksual, semuanya dibicarakan secara terbuka sehingga sangat mudah untuk sampai ke telinga suami Tandha' baik langsung maupun tidak.

Melihat realitas tersebut ditambah dengan kuatnya hegemoni kuasa agama yang menggembur eksisitensi tubuh perempuan Tandha' Madura, wajar jika menjadi sulit bagi orang untuk membayangkan tayub bisa hidup dan berkembang di Sumenep. Padahal kenyataannya Tandha' bisa dikatakan hiburan favorit bagi orang orang desa Sumenep. Perempuan Tandha' menjadi sosok yang dirindu juga dibenci.

Beragam definisi yang dilekatkan pada sosok perempuan tandak ini tidak terlepas dari konstruksi makna tubuh yang melekat padanya (Anoegrajekti, 2007: 06-07). Pengertian maknawi rupanya sangat tergantung pada siapa yang merumuskannya. Hal ini tentu saja dipengaruhi oleh sederet referensi dan kepentingan yang tali temali dengan posisi dan eksistensinya dalam pergaulan sosial yang lebih luas. Justru referensi dan kepentingan itulah yang mungkin lebih intensif terlibat dalam proses perumusan. Konstruksi sosial budaya atas pemaknaan tubuh perempuan tandha' ini baik dalam ranah publik ataupun privat, menjadikan perempuan pada posisi subordinat sehingga menyebabkan kerentanan sosial baik secara fisik, reproduksi (kesehatan), dan bahkan keberadaan atau eksistensi perempuan itu sendiri.

Anoegrajekti (2006) menuturkan betapa kesenian yang mengandalkan tubuh penari perempuan seperti gandrung selalu berada dalam kungkungan relasi kuasa: agama-pasar-birokrasi yang mengakibatkan hilangnya otonomi terhadap tubuh mereka sendiri. Hal senada diungkap oleh Foucault (1979: 25-27) yang memaparkan bahwa tubuh juga menjadi wilayah di mana relasi kuasa 
berjalan di atasnya. Relasi kuasa itu melatih, memaksa, menyiksa, menandai, menanamkan kekuatan dan menguasai tubuh. Namun menurutnya teknologi politis terhadap tubuh tidak dapat dilokalisasi pada tipe tipe tertentu institusi atau aparat negara; karena mereka memiliki jalan lain terhadapnya; mereka menggunakan, menyeleksi atau menentukan hal hal tertentu dari metodenya. Apa yang dioperasikan oleh aparat dan istitusi tersebut adalah sebuah mikro fisika dari kuasa, yang mengandaikan kuasa dilaksanakan dalam tubuh bukan sebagai milik tetapi sebagai strategi. Jadi, kuasa lebih dilaksanakan daripada dimiliki. Kuasa dilaksanakan dalam berbagai relasi di masyarakat dan tidak terbatas dalam bentuk hubungan pemerintah dengan rakyat atau relasi masyarakat tertentu dengan kelas yang lain atau diterapkannya kewajiban dan larangan.

Fenomena di atas juga terlihat dalam eksistensi perempuan tandha' Madura di desa tanah merah Saronggi, Sumenep. Hal ini terlihat ketika kuasa agama melalui Kiai Nyai, dan dogma dogma agama yang menempatkan tandha' bukanlah ekspresi seni tapi sesuatu laku haram. Demikian juga ketika Dinas Pariwisata dan Budaya Sumenep yang dikenal sebagai institusi pelestari budaya tradisional, alih alih melestarikan, mereka meminta bantuan Kiai untuk melakukan pembinaan terhadap perempuan tandha'. Selain itu berbagai aturan yang diterapkan dalam tata gerak seni tandha', seperti baju yang harus dipakai, jarak antara tandha' dengan penonton, dan berbagai aturan aturan yang lain merupakan bentuk kuasa dan opresi bagi tubuh perempuan tandha'. Fenomena di atas menunjukkan adanya relasi kuasa dalam tubuh perempuan tandha'.

Di sisi lain di tengah beragam makna yang digambarkan pada sosok perempuan tandha' tersebut, eksistensi perempuan tandha' di desa Tanah Merah SaronggiSumenep tetap hadir dengan laku juang yang terus diperankan. Hal ini selaras dengan beragam penelitian etnografis yang menunjukkan seni pertunjukkan tradisional seperti gandrung, tayub, tandak, dan sejenisnya menggambarkan laku juang tubuh seniman perempuan yang harus berjibaku dengan kuasa agama dan budaya patriarki. Usaha laku juang yang dilakukan ini sebenarnya merupakan wujud resistensi dari kuasa yang terjadi.

Meskipun ada dalam konteks diskursif dan surveillance panopticon, individu pada dasarnya bukanlah subyek tanpa daya. Karena kuasa itu tersebar, maka setiap individu adalah aktor dalam proses relasi kuasa, mereka juga memiliki kuasa. Oleh karena itu dalam relasi kuasa selalu ditemukan resistance yang beredar dan berjalan dalam logika saling mempengaruhi (Kendal dan Wickham, 1999: 49)

Resistensi tidak harus selalu berarti melawan dalam arti meruntuhkan kekuasaan. Bentuk resistensi sendiri menurut James Scott dapat diwujudkan dalam dua bentuk yaitu (1) perlawanan terbuka (public transcript) di depan banyak orang seperti contohnya anak perempuan melawan dominasi dari pihak yang kuat (orang tua dan suami), dan (2) perlawanan tertutup (hidden transcript), di luar "panggung" seperti contohnya anak perempuan melawan secara diam-diam atau tersembunyi terhadap pihak yang kuat.

Resistensi adalah kerja penyiasatan yang diperlukan agar relasi kuasa itu ada (Langellier, 1989). Selayaknya sebuah kerja penyiasatan, resistensi muncul dalam muka yang rahasia dan kenikmatan. Gabungan dua spek ini dalam resistensi memunculkan kerja resisten yang bergerak dalam sebuah medan tertutup sekaligus mampu mengelevasi ketertutupan menjadi kenikmatan. Bagaimanapun tubuh secara historis dan kultural adalah titik singgung dari relasi kuasa antara kontrol sosial dan perlawanan. Bentuk perlawanan tidak selalu menentang nilai budaya dan agama yang berkembang di masyarakat Madura tetapi dapat juga berwujud perlawanan secara tersembunyi dalam bentuk perkataan dan praktik seperti desas desus atau melakukan hubungan seksual. 
Pengalaman Komunikasi yang terkuak dari perjalanan hidup seorang tandak, mulai dari pahit manisnya menjadi seorang tandak, godaan ketika menjadi seorang tandak dan masalah bahkan perlawanan yang dilakukan seorang tandak ketika ia mendapat perilaku yang tidak senonoh dari penggemarnya dapat dianalisis dengan bantuan teori resistensi James C. Scott.

Berdasarkan latar belakang di atas, rumusan masalah sebagai berikut: Bagaimana bentuk resistensi perempuan tandhak Madura melalui pengalaman komunikasi di tengah relasi kuasa yang terjadi atas nama tubuhnya. Berdasarkan rumusan masalah di atas, penelitian ini bertujuan untuk menganalisis resistensi perempuan tandhak Madura melalui pengalaman komunikasinya di tengah relasi kuasa yang terjadi atas nama tubuhnya

\section{METODE PENELITIAN}

Penelitian tentang resistensi perempuan tandha' Madura: berjuang dari dalam ini merupakan penelitian dengan metode kualitatif. Penelitian kualitatif ini bertujuan sebagai upaya memperoleh informasi data sampai kedalaman akar permasalahan serta penyebarannya seluas mungkin sebagai penyebab suatu fenomena yang muncul di permukaan. Dalam konteks penelitian ini, akan diungkap perspektif pengalaman sadar perempuan tandha' Madura tentang pengalaman komunikasinya yang akan mencerminkan bentuk resistensi yang dilakukan di tengah pusaran relasi kuasa yang terjadi di tubuhnya. Untuk memperoleh gambaran yang menyeluruh tentang pengalaman sadar perempuan madura dilakukan pendekatan etnografi. Kajian etnografi memfokuskan telaah fenomena budaya yang memberikan gambaran umum masyarakat yang mempunyai kehidupan tersendiri secara spesifik (Spradley, 2007).

Jenis etnografi modern yang dipakai dalam penelitian ini adalah etnografi feminis. Etnografi feminis yaitu studi mengenai perempuan dalam praktik budaya yang merasakan pengekangan akan hak haknya (L.R. Gay, 2009). Penelitian ini menggunakan pendekatan etnografi feminist untuk memahami dan menginterpretasikan pengalaman, perasaan dan pemikiran yang tersembunyi dalam diri perempuan madura.

Penelitian dengan pendekatan etnografi feminist memokuskan perhatiannya bukan pada gejala yang terjadi atau fenomena yang nampak. Tetapi justru fokus perhatiannya ada pada apa yang ada dibalik yang nampak, hal tersebut tersembunyi dibenak dan pemikiran perempuan tandha' madura sebagai Noumena. Membedah noumena dapat dilakukan dengan wawancara, observasi dan pengamatan atau observasi langsung melalui berbagai perilaku yang ditampilkan informan selama penelitian berlangsung.

Pendekatan etnografi feminis dalam penelitian ini akan melakukan pendokumentasian kehidupan dan aktivitas perempuan tandha' madura; memahami pengalaman perempuan tandha' madura dari sudut pandang mereka sendiri dan sebagai ekspresi dari konteks sosial tertentu. Kajian etnografi feminis dalam penelitian ini nantinya menjadi cara untuk mengungkap pengalaman komunikasi yang dialami perempuan tandha' madura khususnya berkaitan dengan bagaimanakah resistensi yang dilakukan perempuan tandha' madura dalam pusaran relasi kuasa yang terjadi di atas tubuhnya.

Subjek dalam penelitian ini adalah perempuan tandha' Madura di desa tanah Merah kecamatan Saronggi Sumenep Madura. Terdapat kriteria khusus dalam pemilihan informan yaitu :

1. Tandha' sebagai informan kunci, ditentukan dengan kriteria: masih aktif sebagai tandha'; bertempat tinggal di desa tanah merah kecamatan saronggi sumenep; berprofesisebagai tandha' lebih dari 5 tahun. Tandha' Sahniyah, Susmiyati, Hj Ahwiyani, Fitri dan luluk merupakan tandhak tandhak yang berada 
di lingkungan desa tanah merah dan merupakn informan dalam penelitian ini.

2. Selain informan utama di atas, dalam penelitian ini juga dibutuhkan informasi tambahan yang dipilih berdasarkan kriteria berikut:

a. Pengrawit (nayaga/ najhagha) adalah penabuh gamelan di karawitan yang mengiringi tandha'. Pengrawit yang dipilih sebagai informan dalam penelitian ini adalah pengrawit yang senior atau memimpin kelompok karawitan atau memiliki jam terbang tinggi dalam mengiringi tandha' atau juga pernahmengalami ron toron (naik ke pentas untuk menari dan ngejung mendampingi tandha'). Asyati, dan Sumarti adalah pengrawit yang memiliki kriteria sebagi informan dalam penelitian ini.

b. suami dari perempuan tandha' informan utama atau suami dari pengrawit (najhege). Musappak suami dari pengrawit asyati, serta A. Suharto suami dari tandha' Susmiyati merupakan informan tambahan yang terpilih dalam penelitian ini.

c. tokoh masyarakat yang mengetahui tentang budaya Madura khususnya tentang perempuan tandha' Madura. K. H Ismail, Edy setiawan serta $\mathrm{Ny}$. Hj Patimah adalah wakil dari tokoh masyarakat yang menjadi informan dalam penelitian ini.

Penelitian yang dilakukan ini membahas tentang resistensi yang dilakukan perempuan tandha' Madura yang tercermin lewat pengalaman komunikasi yang mereka alami. Berdasarkan tema diatas, yang menjadi obyek penelitiannya adalah pengalaman komunikasi perasaan dan pemikiran perempuan tandha' Madura di wilayah kecamatan Saronggi Sumenep Madura.

Lokasi penelitian ini, ada di desa Tanah Merah kecamatan Saronggi, kabupaten Sumenep Madura. Selain itu penggalian data pada informan dalam hal ini perempuan tandha' Madura juga diperoleh dari lokasi ruang aktivitas perempuan tersebut yang terbagi dalam wilayah privat (dalam rumah tangga mereka) dan juga wilayah public dalam hal ini panggung kesenian tandha'/karawitan, tempat informan itu juga beraktivitas di dalamnya.

Dalam penelitian ini teknik pengumpulan data dilakukan dengan wawancara yang tidak terstruktur atau sering disebut wawancara mendalam (indepth interview). Wawancara dalam penelitian ini dilakukan pada perempuan tandha' Madura di desa Tanah Merah kecamatan saronggi, wawancara tidak terstruktur ini juga dilakukan pada informan tambahan yakni suami informan kunci dan tokoh masyarakat yang mengerti tentang budaya Madura khususnya tentang perempuan tandha' madura.

Selain itu, dalam penelitian ini juga digunakan teknik pengumpulan data observasi untuk menggambarkan keadaan perempuan tandha' Madura yang diobservasi. Penelitian ini lebih banyak mengungkap hal hal yang bersifak privat dan pengalaman hidup perempuan tandha sehingga sangat diperlukan kepekaan terhadap lingkungan dengan penuh kesadaran. Interaksi dengan informan juga suatu cara untuk mengamati perilaku informan, sehingga kecermatan dalam memperhatikan mimic wajah dan bahasa tubuh juga turut merupakan data disamping kalimat verbal yang dikeluarkan informan. Terkadang bahasa tubuh lebih bisa memperlihatkan apa yang sebenarnya tengah terjadi jika informan tidak dapat mengeluarkan semua hal yang dirasakannya.

Observasi pada penelitian ini diarahkan pada aspek-aspek komunikasi antar pribadi perempuan madura dalam interaksi mereka di ruang privat dan ruang public. Aspek aspek tersebut antara lain bagaimana penampilan pelaku komunikasi mengekspresikan diri, dan beraktivitas termasuk ketika mereka diatas panggung. Suasana lingkungan komunitas dimana interaksi terjadi meliputi interaksi antar individu, keragaman latar belakang kelas 
sosial dan kepemilikan penghasilan serta relasi gender mereka di masyarakat. Observasi juga dilakukan pada lingkungan masyarakat di tempat terjadinya interaksi dan komunikasi, juga bila ada hal-hal menarik yang mendukung dan memperkaya data penelitian ini.

Analisis data dimulai dengan menetapkan orang-orang yang akan dijadikan narasumber baik informan kunci maupun informan pendukung, dan membuat pedoman observasi, pedoman wawancara serta panduan memperoleh data sekunder. Untuk mencari hal-hal menarik dalam penelitian ini, dilakukan pendekatan informan dengan berbagai cara di antaranya melalui pengamatan terhadap perempuan tandha' madura di dalam wilayah privat dan wilayah publik. Data ini akan memberikan gambaran sekunder ini digunakan dapat memberi gambaran yang menyeluruh mengenai prilaku komunikasi keseharian mereka.

Ada tiga alur dalam proses kerja yaitu reduksi data, penyajian data, dan penarikan kesimpulan. Proses tersebut terjadi secara bersamaan sebagai suatu yang berkaitan saat sebelum, dan sesuah pengumpulan data. Analisis data bersamaaan dengan pengumpulan data.

Dalam penelitian ini validitas atau pemantapan dan kebenaran informasi dicapai dengan menggunakan dua teknik triangulasi yaitu triangulasi sumber dan triangulasi peneliti.

\section{HASIL DAN PEMBAHASAN}

Pengalaman Komunikasi yang terkuak dari perjalanan hidup seorang tandak, mulai dari pahit manisnya menjadi seorang tandak, godaan ketika menjadi seorang tandak dan masalah bahkan perlawanan yang dilakukan seorang tandak ketika ia mendapat perilaku yang tidak senonoh dari penggemarnya dapat dianalisis dengan bantuan teori resistensi James C. Scott. James C. Scott (2000) mendefinisikan Resistensi atau perlawanan sebagai segala tindakan yang dilakukan oleh kaum atau kelompok subordinant yang ditujukan untuk mengurangi atau menolak klaim yang dibuat oleh pihak atau kelompok superdinant terhadap mereka.

Scott (2000) membagi perlawanan tersebut menjadi dua bagian, yaitu: 1 . Perlawanan publik atau terbuka (public transcript), dan 2. Perlawanan tersembunyi atau tertutup (hidden transcript). Kedua kategori tersebut, oleh Scott, dibedakan atas artikulasi perlawanan, bentuk, karakteristik, wilayah sosial dan budaya.

1. Perlawanan terbuka

Perlawanan terbuka dikarakteristikan oleh adanya interaksi. Scott (2000: 17) mengungkapkan bahwa ada empat karakteristik yang menunjukkan perlawanan terbuka, diantaranya sebagai berikut. (1) Perlawanan yang berwujud sesuai sistem yang berlaku, terorganisir antara satu pihak dengan pihak lain, dan saling bekerja sama; (2) Terdapat dampak perubahan (konsekuensi revolusioner) dalam pergerakan yang dapat mempengaruhi kelangsungan hidup; (3) Bersifat rasional dengan berfokus pada kepentingan banyak orang; (4) Bertujuan menghapuskan tindakan dominasi dan penindasan dari kaum penguasa. Perlawanan terbuka mengarah pada pergerakan yang dilakukan secara sistematis dengan koordinasi antara pemimpin dengan anggota yang berperan serta melakukan perlawanan.

2. Perlawanan tertutup (hidden transcript).

Perlawanan tertutup (hidden transcript) adalah bentuk perlawanan yang dilakukan oleh seseorang melalui prosedur yang kurang sistematis. Perlawanan tertutup cenderung mengacu pada gerakan penolakan secara perlahan dengan 
memperhitungkan bentuk perlawanan, capaian yang diperoleh dan penentuan sikap individu dalam mengorganisasi keinginan serta kemampuan untuk melakukan perlawanan. Scott (2000: 17) menjelaskan bahwa ada empat karakteristik perlawanan tertutup, diantaranya sebagai berikut; (1) Terjadi secara tidak teratur; (2) Tidak terorganisir; (3) Bersifat individual (bertujuan untuk mencari keuntungan dengan berfokus pada kepentingan individu); (4) Tidak mengandung dampak perubahan.

Kedua bentuk resistensi tersebut dapat diamati dalam pengalaman komunikasi perempuan Tandha' Madura berikut ini:

Pengalaman komunikasi yang mencerminkan adanya relasi kuasa dalam tubuh perempuan tandhak madura di Tanah Merah Saronggi Sumenep dapat diamati dalam eksistensinya di wilayah publik. Profesi tandha' sejatinya sudah ada sejak lama di negara kita, termasuk di Madura. Profesi sebagai pekerja seni tradisonal ini biasa juga disebut di daerah lain dengan ledhek, sinden, waranggono. Profesi ini mengalami pasang surut pengakuan posisi di masyarakat.

Menurut Bauvier $(2002 ; 169)$ awalnya tandha' ini berada dalam lingkungan kerajaan sehingga penikmat mereka adalah pejabat pejabat keraton. Namun seiring perkembangan pada tahun 1965 adanya perubahan significant berkaitan dengan cara berbusana yang dianggap kurang sopan sehingga hrus dirubah menjadi kebaya kerah tinggi, lengan panjang dengan leher terbuka. Kejadian ini ternyata malah berdampak pada menurunnya penikmat kesenian ini. Para tandha' akhirnya mencari pelanggan lain di masyarakat umum sehingga dari sinilah mereka menjadi rentan dan dekat dengan prostitusi.

Sejak saat itu strereotif negatif melekat dalam diri mereka sebagai pelacur, tidak taat agama, bukan wanita ideal.
Beragam kuasapun selanjutnya hadir ikut mengatur tubuh mereka.

Stereotip negatif juga berkembang kuat di lingkungan masyarakat agamis. Kiai (agama) sebagai sosok penting dalam kehidupan masyarakat Madura, khususnya Sumenep yang mayoritas muslim, menunjukkan penolakan sikap yang sama dengan pemerintah (negara), malah lebih ekstrem. Kiai yang mulanya terbagi menjadi golongan moderat dan konservatif pada akhirnya tetap menempatkan tandha' di satu suara, yaitu haram. Hal ini terlihat ketika kuasa agama melalui Kiai, Nyai, dan dogma dogma agama yang menempatkan tandha' bukanlah ekspresi seni tapi sesuatu laku haram. Patimah

Hal ini seperti yang dipaparkan Nyai "jika kesenian itu meninggalkan manfaat,
meninggalkan kebajikan dan ada nuansa
pelanggaran, maka dia bisa mengarah pada
haram” (Wawancara, Nyai Patimah 21
Februari 2019)

Beberapa kiai dan nyai bahkan ada yang tidak berseda datang mengisi ceramah jika di acara tersebut ada acara tandha', seperti yang dipaparkan Nyai Patimah berikut:

"Kalau saya sebenarnya tidak
membedakan bedakan siapa yang
mengundang. Hanya saja saya harus yakin
darimana asal rezeki yang dia dapat hahal
atau haram" (wawancara, Nyai Patimah
21 Februari 2019)

Di tengah beragam sikap yang digambarkan pada sosok perempuan tandha' tersebut, eksistensi perempuan tandha' di Tanah Merah Saronggi-Sumenep tetap hadir dengan laku juang yang terus diperankan. Usaha laku juang yang dilakukan ini sebenarnya merupakan wujud resistensi dari kuasa yang terjadi.

Hal ini terlihat dari sikap yang dilakukan oleh perempuan tandha' madura seperti dalam kutipan wawancara berikut:

"Ya pasti saya sedih mbak dengar omongan itu. Nangis mbak saya. Ya 
bagaimana ya. Saya itu kerja cari uang buat anak keluarga kabeeh. Gak aneh aneh kok dibilang haram... la kalau saya gak kerja mbak...gimana mbak.... anak saya gak makan mbak..."

"Jadi ya sudah mbak..nangis sudah berhari hari saya mbak sampai ngak mau makan sampek saya pikir ya saya gak bisa nangis terus anak nutuh makan mbak ya wis saya kerja lagi mbak... biar wes orang ngocak apa..gak pa pa pokoknya saya ya mbak ya gak buat salah apa menyakiti ya mbak rang orang itu... saya juga masih sholat kok mbak..trus kalau ada rejeki ya mbak...gitu saya nyumbang mbak buat masjid.. ya itung itung ilangin dosa sedikit sedikit mbak." (wawancara Susmiyati, 2 maret 2020)

Meskipun ada dalam konteks diskursif dan surveillance panopticon, individu pada dasarnya bukanlah subyek tanpa daya. Karena kuasa itu tersebar, maka setiap individu adalah aktor dalam proses relasi kuasa, mereka juga memiliki kuasa. Oleh karena itu dalam relasi kuasa selalu ditemukan resistance yang beredar dan berjalan dalam logika saling mempengaruhi (Kendal dan Wickham, 1999: 49)

Dari sikap yang ditunjukkan tandak susmiyati tersebut terlihat dari pengalaman komunikasinya mengakibatkan dia memilih perlawanan atau resistensi awalnya secara hidden transkript yaitu dengan cara menagis. Namun stelah merasa tenang diapun memilih resistensi public transkrip dengan tetap melanjutkan menari tandha' sebaik dan setotal mungkin untuk lebih menarik perhatian dan menimbulkan ketergantungan bagi penikmatnya. Namun ini semua tetap dilakukan dengan berusaha untuk berbuat baik dan tidak meninggalkan perintah agama yaitu sholat dan zakat. Resistensi public transkrip yang dilakukan perempuan tandha' ini terlihat dari pengalaman komunikasinya yang memilih diam dan tidak menghiraukan hujatan yang tertuju padanya tapi terus memilih untuk menari. Uang yang dihasilkannya dari menandak terkadang dengan sengaja dia disisihkan cukup banyak untuk dizakatkan. Selain agar bisa barokah salah satu tujuan prilakunya adalah untuk pembuktian dan membalas "hinaan' kepada pihak pihak yang kontra (kiai/pesantren) bahwa tandha' pun mampu untuk berzakat, seperti dalam kutipan wawancara berikut:
"ya, pernah mbak..pas edapat pese' banyak ..e habis tandha' saya kasihkan ke masjid. E..ya cukup banyak juga... ya semoga jadi barokah... tapi ya sebenarnya ehemm...biar tau mereka kalau tandha'itu juga bisa zakat.. (wawancara susmiyati, 2 maret 2020)

Tapi ada juga tandha' yang memilih menghindar dari aktifitas keagamaan karena gak mau terus dihina dan dijadikan bahan cemooh. Beberapa dari para tandha' tidak hadir dalam acara mamacah atau macopat. Mereka ada juga yang memilih untuk membatalkan niat menyumbang ke masjid dan lebih memilih meminjamkannya pada tetangga yang sedang membutuhkan, seperti dalam kutipan wawancara berikut:

\begin{abstract}
"pernah mbak...saya memang niat mau nyumbang ke masjid, tapi karena tau kiai itu bilang kalau uang hasil trandha' itu uang haram.... ya saya marah mbak... saya gak jadi nyumbang ... ya lebih baik saya pinjamkan ke tetangga yang kebetulan butuh mbak... ya gimana saya kok rasanya sakit dan gak rela kalau hasil keringat saya itu diharamkan... (wawancara Ahwiyani, 4 April 2020)"
\end{abstract}

Pengalaman komunikasi perempuan tandha' Madura sebagai bentuk adanya relasi kuasa yang terjadi juga terlihat ketika Dinas Pariwisata dan Budaya Sumenep yang dikenal sebagai institusi pelestari budaya tradisional, alih alih melestarikan, mereka meminta bantuan Kiai untuk melakukan pembinaan terhadap perempuan tandha'. Selain itu beragam usaha pemerintah (negara) merasa penting untuk mentralkan identitas tandha' dalam masyarakat. Pemerintah, yang kebanyakan diwakili oleh wanita kelas menengah Madura, melakukan penetralan tanpa bisa menghilangkan stereotip negatif terhadap tandha'. Penetralan terhadap tandha' justru memaksanya untuk mengganti rapé dengan kebaya, setelah 
memakai kebaya tandha' disuruh untuk memakai jilbab, kéjhung merdu yang berisi godaan manis untuk laki-laki diganti dengan solawat nabi, tidak boleh ada ron-toron agar tayub menjadi lebih tertib, jarak penari lakilaki dengan tandha berjarak satu meter dan tidak boleh jawil-jawil. Penetralan ini dianggap sebagai pembelaan pemerintah terhadap tandha' di mata masyarakat agar martabat tandha' dapat terangkat. Namun sesungguhnya berbagai aturan aturan tersebut sejatinya merupakan bentuk kuasa dan opresi bagi tubuh perempuan tandha'. Fenomena di atas menunjukkan adanya relasi kuasa dalam tubuh perempuan tandha'. Perempuan tandha' Madura seakan tak memiliki kuasa atas tubuh mereka sendiri. Reproduksi identitas tandha sama saja dengan pengakuan hegemoni kuasa pemerintah terhadap golongan marjinal seperti tandha'. Dengan segala kekuatan dan kuasa-nya pemerintah dapat mengganti atau bahkan melenyapkan suatu budaya marjinal untuk menegakkan dominasi di sisi lain

Bentuk perlawanan atau resistensi yang dilakukan tandha' madura, khususnya tandha' tandha' muda, tidak selalu menentang nilai budaya dan agama yang berkembang di masyarakat Madura tetapi dapat juga berwujud perlawanan secara tersembunyi dalam bentuk mengikuti perbuatan yang diinginkan pemilik kuasa tersebut. Hal ini bukan menunjukan kepatuhan dan tidak berdaya namun merupakan stategi agar tetap survive. Seperti dalam kutipan wawancara berikut:

\footnotetext{
"Iya dek..sekarang tandha' itu harus punya kartu iya itu nomor induk... itu kalo' gak punya ato gak bawa ya gak boleh mangung...kalau saya ya nurut aja dek pokok bisa mangung dapat uang e..kartune kiya dek..saya bawa bawa terus di dompet kiya..sama itu ada aturan juga..bajunya harus panjang gak ole apa kemben gitu dek.trus gak dekat dekat dek iya ...ada jaraknya.. awalnya ya apa..ya dek aneh gak biasa yo ... semua tandha' itu apa itu... ngomel gitu lo dek..memang jadi aneh ...tapi ya trus mau aja daripada dibubarkan. (Saniyah, wawancara 1 maret 2019)
}

Namun tidak berarti semua tuntutan aturan dari pemilik kuasa yang dominan seperti pemerintahan dituruti oleh perempuan tandha' Madura. Ada hal hal yang mereka menolak untuk melakukannya seperti ketika dinas pariwisata Sumenep menyusun regulasi bahwa tandha' harus berpakaian sopan dan berjilbab. Hal ini seperti terlihat dalam kutipan wawancara berikut:

\begin{abstract}
"kalau kita yang penting itu dek masih bisa terus manggung. Karena ya dek saya dan anak anak bisa makan ya dari tandhe' itu... saya gak punya apa apa dek kalau gak oleh tandhe'...trus kelaurga saya nanti makan apa. Kalau masalah pakaian ya.. gak papa diruti aja wong ya tambah cantik tak iye sayanya...tapi kalau masalah harus pakai jilbab kalau nandha' kok enggak ya dek... rasanya kok aneh nanti... jadi kita ya milih tetap gini aja gak papa ya. (wawancara Ahwiyani, 4 April 2020
\end{abstract}

Selain interaksi tandha' di wilayah publik, bentuk resistensi juga terlihat dari pengalaman komunikasi perempuan tandha' di wilayah domestik.Dalam wilayah domestik, relasi kuasa juga terlihat dari interaksi perempuan tandha' dengan lingkungan keluarga seperti suami dan keluarga dekat.

Dalam konteks relasi laki-laki perempuan, bagi masyarakat madura, kepemimpinan berada di tangan laki laki. Posisi perempuan tertata dalam norma dan praktik sosial yang berlaku. Tempat perempuan berada di dalam rumah dan posisinya adalah sebagai makhluk yang berada dalam pengawasan dan pemilikan laki laki. Konteks relasi ini seakan tidak terlihat dari relasi perempuan tandha' dengan suami dan keluarganya. Sebagian besar tandha' mengawali hidupnya sebagai seorang tandha' karena masalah ekonomi yang menderanya. Inilah awal yang mengubah tatanan konteks relasi laki laki dan perempuan dalam kehidupan keseharian tandha'. Norma dan praktik sosial yang menempatkan perempuan berada dalam rumah menjadi tidak berlaku ketika perempuan ini menjadi tandha'. 
Aktivitas keseharian demi mencukupi perekonomian keluarga dan bertahan hidup memaksa perempuan tandha' tidak berada di dalam rumah bahkan sampai dini hari. Dalam banyak waancara dengan sejumlah tandha', mereka menyatakan bahwa merekalah sebenarnya kepala keluarga karena mereka yang mencari uang, mendanai kebutuhan keluarga, menyekolahkan anak, sampai memutuskan untuk membeli atau tidak membeli sesuatu.

Pilihan menjadi tandha' membawa mereka pada posisi penyangga ekonomi keluarga. Hal ini juga berlaku bagi tandha' yang belum memilki suami atau sedang menjanda. Mereka juga yang akan menanggung seluruh kebutuhan hidup orang tua dan saudara saudaranya. Dalam situasi seperti ini, perempuan tandha' memiliki modal ekonomi yang dapat dijadikan sebagai modal resistensi mereka baik secara hidden transkrip maupun publik transkrip. Resistensi publik transkrip terlihat dimiliki perempuan tandhak ketika mereka dilarang oleh suaminya menjadi tandha' lagi. Keberanian untuk memilih bercerai daripada mundur dari tandha' menjadi buktinya. Hal ini seperti yang diungkapkan Ahwiyani dalam kutipan berikut:

\footnotetext{
"kalo tengkar karena cemburu awalnya sudah saya jelaskan mbak...tapi pernah itu ngak percaya tengkar terus sampai ngajak cerai... ya silahkan ayo cerai kalo berani...dulu saya yang takut ke dia sekarang dia yang takut ke saya.." (wawancara Ahwiyani, 3 April 2020)
}

Relasi kuasa yang terjadi dalam tubuh tandha' juga dapat diamati dari Pengalaman komunikasi tandha' ketika berada di atas dunia panggung. Secara umum ketika berada di atas panggung kuasa dominan nampak dimiliki perempuan tandha'. Tandha' yang mempunyai kuasa dengan siapa dia akan menari melalui sampur yang dikalungkan pada penayub pilihannya. Demikian hal nya ketika penayub terlihat mulai bertindak kurang sopan, maka tandha' akan melakukan resistensi baik secara hidden transkrip seperti gerakan melemparkan sampur dan langkah kaki menjauh hingga resistensi secara publik transkrip seperti menampar penayub dan menghentikan tarian serta gamelan karawitan yang mengikutinya.

Sebagai bagian dari masyarakat, dalam pengamatan yang dilakukan peneliti, Tandha' juga mengikuti kegiatan sosial masyarakat di lingkungannya seperti pada umumnya. Tidak ada yang berbeda dalam penampilan dan aktifits keseharian mereka di tengah masyarakat seperti datang ke arisan, pkk dan lain lain dengan dandanan yang tidak jauh berbda dari wanita wanita madura pada umumnya. Namun yang cukup membedakan adalah perhiasan yang cukup menyolok yang mereka kenakan ketika mereka bertemu dan berinteraksi dengan tetangga. Penampilan yang terkesan menunjukkan keberhasilan ekonomi seorang tandha' ketika mereka berinteraksi dengan masyarakat sekitar menjadi bentuk bukti resistensi publik transkrip mereka. Perhiasan, mobil, rumah mewah menjadi modal simbolik yang menunjukkan keberasilan mereka sebagai seorang tandha'.

Demikian halnya dengan relasi yang terjadi antara tandha' dengan tetangga sekitarnya. Dalam observasi peneliti di desa Tanah Merah Kecamatan Saronggi Sumenep diketahui masyarakat sekitar rumah tandha' cenderung tidak menolak keberadaan mereka. Selain karena cukup banyak tandhak yang ada di desa tersebut, masyarakat juga sudah menganggap tandha' sebagai profesi yang menjanjikan secara perekonomiannya. Hal ini karena warga sekitarpun turut merasakan dampak dari baiknya perekonomian tandha' di sekitar mereka. Tandha' bisa dijadikan sebagai tempat bergantung jika merek kesulitan dalam keuangan. Tandha' Sahniyah, Susmiyati, Hj Ahwiyani, Ida kendel, Fitri dan luluk merupakan tandhak tandhak yang berada di lingkungan desa tanah merah. Mereka sebagian besar mempunyai prinsip untuk peduli pada masyrakat sekitar seperti memberi pinjaman ketika mereka membutuhkan karena selama ini para tetangga telah mensuport kegiatan mereka. 
Dari observasi pengalaman komunikasi tandha' desa Tanah Merah Saronggi Sumenep Madura diatas, terlihat strategi resistensi yang dilakukan tandha' madura ini dengan cara menjadikan modal ekonomi yang mereka miliki sebagai pengganti modal sosial yang tidak mereka miliki karena akibat strereotif negatif tandha' yang melekat didirinya. Strategi mencapai modal ekonomi mereka lakukan dengan pengalaman komunikasi berupa kerja keras untuk memperoleh hasil (kekayaan) yang maksimal, dengan berusaha seoptimal mungkin menjadi tandha' senior (idaman banyak orang). Selanjutnya modal ekonomi tersebut mereka tampilkan dalam modal simbolik berupa perhiasan yang banyak dan mewah yang selalu mereka pakai dalam setiap acara bersosialisasi dengan masyarakat sekitar, jumlah mobil dan rumah yang mewah, menyumbang masjid dan fakir miskin, serta memposisikan diri sebagai sosok yang paling dibutuhkan ketika tetangga sekitar memerlukan bantuan seperti memberi pinjaman pada tetangga.

Hal ini sejalan dengan pendapat Bourdieu (dalam Fashri, 2014) bahwa habitus tidaklah ditentukan secara penuh oleh sruktur struktur dan agen mendapatkan kembali kreasinya melalui posisi posisi yang terdapat dalam sebuah ranah, maka situasi ini membuka ruang yang besar bagi agen untuk menggunakan pelbagai stategi. Menurut Bourdiue (1991:14) strategi yang dipakai para pelaku berdasarkan pada jumlah modal dalam posisinya di ruang sosial. Jika mereka berada dalam posisi dominan maka strateginya diarahkan kepada upaya melestarikan dan mempertahankan status quo, sementara mereka yang didominasi berikhtiar mengubah distribusi modal, aturan main, dan posisi posisinya sehingga terjadi kenaikan jenjang sosial atau minimal survive dan berdamai dengan kelompok dominan. Kesempatan untuk menang atau kalah bergantung pada penguasaan para pelaku atas modal dan posisi posisi yang ditempati mereka dalam struktur kekuasaan

\section{PENUTUP}

Pengalaman komunikasi perempuan tandha' di desa tanah merah Saronggi Sumenep madura menunjukkan adanya resistensi yang dilakukan sebagai bentuk adanya proses relasi kuasa. strategi resistensi yang dilakukan tandha' madura ini dengan cara menjadikan modal ekonomi yang mereka miliki sebagai pengganti modal sosial yang tidak mereka miliki karena akibat strereotif negatif tandha' yang melekat didirinya. Bentuk resistensi yang nampak terlihat dari pengalaman komunikasi perempuan tandha' ini dilakukan baik secara hidden transkript maupun public transkript. Hidden transkript terlihat dari pengalaman komunikasi tandha' berupa tangisan, gerutuan, kibasan sampur tanda menolak penayub yang terlalu menganggu, gerakan langkah menjauh, menyetujui untuk memikili NIK, tidak berpakaian kemben dan menjaga jarak ketika menari dengan pasangan. Selain itu bentuk resistensi yang berupa public transkript juga terlihat dari pengalaman komunikasi perempuan tandha'. Menolak dengan tegas untuk tidak memakai hijab ketika menari, Memilih tetap menjadi tandha' meski banyak yang mencemooh dan mehujat serta melarang baik dari keluarga maupun orang sekitarnya merupakan bentuk public transkript yang terjadi. Selain itu keberanian dia untuk memilih bercerai ketika suami melarang mereka menari, menunjukkan perempuan tandha' memiliki bargaining power. Hal ini disebabkan mereka memilki modal ekonomi yang merupakanpengganti dari modal sosial yang tidak mereka miliki. Strategi resistensi yang dipilih perempuan tandha' dengan mengejar modal ekonomi sebagai pengganti modal sosial merupakan bentuk kongkrit public transkript yang mereka lakukan. Dengan modal ekonomi mereka memeliki kuasa lebih untuk menentukan apa yang ingin mereka lakukan termasuk bernegosiasi dengan situasi. Strategi mencapai modal ekonomi mereka lakukan dengan pengalaman komunikasi berupa kerja keras untuk memperoleh hasil (kekayaan) yang maksimal, 
dengan berusaha seoptimal mungkin menjadi tandha' senior (idaman banyak orang). Selanjutnya modal ekonomi tersebut mereka tampilkan dalam modal simbolik berupa perhiasan yang banyak dan mewah yang selalu mereka pakai dalam setiap acara bersosialisasi dengan masyarakat sekitar, jumlah mobil dan rumah yang mewah, menyumbang masjid dan fakir miskin, serta memposisikan diri sebagai sosok yang paling dibutuhkan ketika tetangga sekitar memerlukan bantuan seperti memberi pinjaman pada tetangga.

Sekilas memang kuasa itu seakan tak terlihat tertutup dengan opresi yang seakan terus mereka dapatkan dari berbagai pihak. Sebagain orang mungkin beranggapan bahwa mereka menyerah dan tidak punya kuasa, Namun kuasa yang terjadi di wilayah ini adalah kuasa yang bersifat produktif tidak mengopresi dan teropresi. Hal ini seperti yang diungkapkan Scott (1985)perlawanan kaum marginal ditandai dengan kelenturan dan ketahanan diri. Tujuan utamanya memang tidak langsung menjatuhan atau mengubah sistem dominasi melainkan untuk bertahan hidup di tengah sistem tersebut.

\section{DAFTAR PUSTAKA}

Anoegrajekti, Novi. (2006). "Gandrung Banyuwangi Pertarungan Pasar, Tradisi, dan Agama memperebutkan Representasi Identitas Using”. Disertasi Tidak Diterbitkan. Depok: Program Pascasarjana Fakultas Ilmu Budaya Universitas Indonesia.

Anoegrajekti, Novi. (2007). Biarkan dia mendefinisikan Diri" dalam SRINTIL: Media Perempuan
Multikultural edisi 13. Jakarta: kajian Budaya Desantara.

Bourdiue, Pierre. (1991). Languange and Simbolic Power. Cambridge: Polity Press

Bouvier, H. (2002). Lebur! Seni Musik dan Pertunjukan dalam Masyarakat Madura. Jakarta: Obor.

Foucault, Michel. (1979). Discipline and Punish. New York: A Division of Random House, Inc. vintage Books.

Kendal, D dan Wickham G. (2003). Using Foucault Methods. London: Sage Publisher

Langellier, K, (1989). Women personal narratives: Strategies of Resistence. Annual Meeting, Speech Communication Association. San Francisco.

L.R. Gay, Geoffrey E. (2009). Mills\&Airasian, Educational Research: Competencies for analysis and application. New Jersey: Merril-Pearson Education

Scott, James C. (1985). Weapons of the Weak: Everyday Fors of Peasant Resistance. New Haven \& London: Yale University Press.

Scott, James C. (2000). Senjatanya OrangOrang Yang Kalah. Jakarta: Yayasan Obor Indonesia.

Spradley, James P. (2007). Metode Etnografi (terjemahan). Yogyakarta: Tiara Wacana 